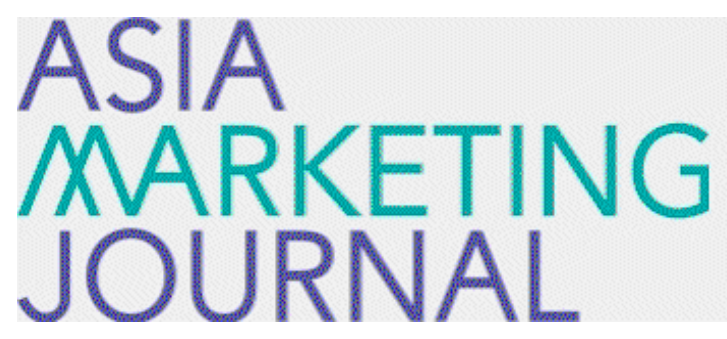

ASIA MARKETING JOURNAL

Volume 2 | Issue 4

Article 1

$12-1-2000$

\title{
신제품 프리어나운싱의 전략적 특성에 관한 연구
}

Heon Soo Jung

Follow this and additional works at: https://amj.kma.re.kr/journal

Part of the Marketing Commons

\section{Recommended Citation}

Jung, Heon Soo (2000) "신제품 프리어나운 싱의 전략적 특성에 관한 연 구," Asia Marketing Journal: Vol. 2 : Iss. 4 , Article 1.

Available at: https://doi.org/10.53728/2765-6500.1049

This Article is brought to you for free and open access by Asia Marketing Journal. It has been accepted for inclusion in Asia Marketing Journal by an authorized editor of Asia Marketing Journal. 


\title{
신제품 프리어나운싱의 전략적 특성에 관한 연구*
}

\section{A Study on Characteristics of New Product Preannouncing Strategy}

\author{
정헌수(건국대학교 경영대학 조교수) \\ hjungkor@kkucc.konkuk.ac.kr
}

\begin{abstract}
대부분의 서구 하이태크 기업들이 "신제품 프리어나운싱 (new product preannouncing)"을 공 식적인 신제품 개발, 출시 전략의 일부분으로 채택, 활용하고 있다. 최근 미국 학계에서도 이 분야에 대한 연구관심이 급속히 중가하고 있지만, 한국에서는 신제품 프리어나운싱이라 는 개념조차 제대로 알려져 있지 않은 상황이다. 따라서 본 연구는 신제품 프리어나운싱에 대한 개념적 고찰 및 미국에서의 기존 연구 성과를 요약, 제시한다. 이를 퉇해 한국 하이테 크 기업들이 프리어나운싱 전략을 활용, 신제품의 성공가눙성을 높이는데 도움을 주고자 하 며, 아울러 이 분야에 대한 한국에서의 향후 연구에 실마리를 제공하고자 한다. 본 연구는 먼저 신제품 프리어나운싱의 개념적 특성, 사례 및 신제품 프리어나운싱에 수반되는 혜택 및 위헙을 구체적으로 기술한다. 그리고 신제품 프리어나운싱 의사결정과 관련된 개녑적 모 형도를 개발, 제시하며, 관련된 기존 연구 및 향후 이 분야에서 요구되는 연구내용 들을 요 약, 제시한다.
\end{abstract}

"논문접수: 00.12 게재확정: 01.02 


\section{1. 연구목적}

하이테크 시장에서 신제품 프리어나운싱 전략은 공식적인 신제품 출시전략의 일부로 받아 들여지고 있다 (Computerworld 1994, Eliashberg and Robertson 1988, Jung and Steckel 2000). 하이 테크 제품의 경우 제품톡성상 고 난이도의 기술이 제품에 구현되기 때문에 소비자들이 제품 의 톡성이나 효능둥에 관한 충분한 지식을 갖지 못한 상태에서 해당제품을 구매하는 경우가 많다. 따라서 하이테크 시장에서는 기업과 소비자간의 심리적인 플레이가 해당제품의 구매 에 결정적인 역할율 할 수가 있다.

신제품 프리어나운싱은 하이테크 시장에서 신제품 출시와 관련하여 활용될 수 있는 주요 한 소비자와의 심리적 플레이 전략으로 인식되고 있다 (Arthur 1996). 하이테크 제품의 경우 일반적으로 제품수명주기가 위협적으로 짭은 경우가 많다. Standard\&Poor's (1998) 에 따르면 PC 산업의 경우 제품수명주기가 평균 1 2 년을 넘지 못하는 것으로 보고되고 있다. 따라서 하이테크 기업들은 해당 제품으로부터 충분한 채산성을 확보하기 위해 신제품 출시 전에 소 비자들을 대상으로 해당 신제품에 관해 공식적으로 정보를 제공함으로써 미리 수요를 확보 할 유인을 갖게 되는 것이다.

신제품 프리어나운싱의 전략적 중요성에도 블구하고 현재 이 분야의 연구성과는 미미한 실정이다. 신제품 프리어나운싱과 관련하여 미국에서 현재까지 행해진 연구들은 기업이 신 제품 프리어나운싱을 하는 이유와 이에 대한 경쟁자들의 반웅에 초점을 맞추고 있다. 한국 에서 이 분야의 연구는 전무한 상황인데 신제품 프리어나운싱 전략의 개념적 특성조차 잘 알려져 있지 않다.

따라서 본 연구는 신제품 프리어나운싱 전략에 관한 기존의 연구 결과들을 바탕으로 이 분야의 개념적 고찰을 시행하고자 한다. 향후 IT 둥 첨단산업의 용성으로 신제품 프리어나 운싱 전략의 중요성이 배가뒬 것으로 예상되므로, 이 분야의 개념적 고찰을 통해 한국에서 의 이 분야 연구를 위한 토대를 제공하고 한국 하이테크 기업들이 실제로 프리어나운싱 전 략을 십분 활용, 신제품 성공 확률을 높이는데 도움이 되고자 한다.

\section{2. 신제품 프리어나운싱의 개녑적 정의 및 사례}

신제품 프리어나운싱이란 기업이 신제품을 시장에 출시하기 전에 해당제품에 관한 정보 (보퉁 해당제품의 우월한 제품 질, 출시날짜, 출시가격)를 소비자들에게 미리 공식적으로 공 표하는 전략적 행위이다. 신제품 프리어나운싱이 전략적 행위로 분류둴 수 있는 것은 기업 이 푝정의 전략적 목표를 가지고 의도적으로 신제품 프리어나운싱 행위를 하기 때문이다.

신제품 프리어나운싱온 미국 하이테크 기업들의 경우 $90 \%$ 이상이 공식적인 신제품 출시전 략으로 활융하고 있는 것으로 나타나고 있으며 (Computerworld 1994), 전 산업에 걸쳐서 51\% 에 해당하는 미국 기업들이 사용하고 있는 것으로 보고되고 있다 (Lilly and Walters 1997). 신제품 프리어나운싱의 대표적인 사례들을 살펴보면 다음과 같다.

- 마이크로소프트사의 경우 새로운 원도 프로그램을 시판할 때마다 잠게는 6 개월, 길 
게는 1 년 전에 미리 새 윈도 프로그램의 우수성에 관해 소비자들에게 공표한다. 1994 년 9 월 마이크로소프트는 1 년 뒤 최신기능을 퉁합한 32 비트형 "윈도 95"를 시 장에 출시하겠다고 프리어나운싱 했다. 1 년 뒤인 95 년 8 월 윈도 95 는 전 세계적으 로 시판에 들어갔고 프리어나운싱 전략의 성공덕분으로 시판 4 일만에 미국 내에서 만 100 만개 이상의 매출이라는 기록을 세웠다.

- 1980 년 미국의 컴퓨터 제조희사 Upstart System 은 IBM PC 보다 휠씬 빠르면서도 크 기면에서 IBM PC 보다 $10 \%$ 적고 가격도 $10 \%$ 정도 싼 PC 률 조만간 시장에 내놓겠다 고 프리어나운싱 했다. 많은 벤처 캐피털리스트 들과 AT\&T, NCR, Xerox, ITT 둥 거대 기업들이 수천만 달러의 투자를 자원했고, 많은 소비자들이 이 제품이 시장에 나오 기를 기다렸다. 그러나 막상 시판된 제품은 실망스러운 수준으로 드러나 많은 투자 회사들이 도산 또는 큰 손실을 보았다.

\section{3. 신제품 프리어나운싱 의사결정의 내용}

신제품 프리어나운싱과 관련하여 기업이 내려야 할 의사결정 내용에는 크게 신제품 프리 어나운싱 여부와 프리어나운싱을 하기로 결정했을 경우 구체적인 프리어나운싱 내용 둥 2 가지로 나누어 볼 수 있다.

신제품 프리어나운싱 여부는 해당 기업이 신제품 프리어나운싱의 혜택과 위험을 비교해본 후 결정하게 되는데 Eliashberg and Robertson (1988)은 관리자들과 인터뷰를 퉁해 프리어나운 싱을 사용하는 기업의 경우 프리어나운싱의 혜택에 보다 전략적 초점을 두는 반면, 하지 않 는 기업들의 경우는 위헙에 보다 비중을 두는 것으로 나타내고 있다.

일단 기업이 프리어나운싱을 하기로 결정하고 나면, 구체적으로 프리어나운싱의 실천과 관련하여 3 가지 의사결정을 행해야 한다. 우선 신제품 프리어나운싱 메시지에 어떤 제품 정 보를 담을 것인가를 결정해야 하며, 신제품 프리어나운싱의 목표 대상 집단으로 누구 들을 선정해야 하는가를 결정해야 한다. 아울러, 신제품 프리어나운싱 효과의 극대화를 위해 어떤 미디어 매체를 뿡해 신제품 프리어나운싱을 행할 것인가를 결정해야 한다. 이들 3 가지 의사 결정 내용에 대해 구체적으로 살펴보면 다음과 같다.

1. 프리어나운싱 메시지 내용: 신제품 프리어나운싱 메시지에는 일반적으로 경쟁제품 또 는 자사의 기존 제품 대비 신제품의 기술적 우위에 관한 내용이 중점적으로 기술된다. 기술 적인 우위에 대해 구체적이고도 기술적인 용어들을 사용, 소비자의 신뢰성을 높이는 경우가 많다. 제품에 관한 정보로 신제품의 출시가격이 포함되는 경우도 있는데, 신제품 출시시점은 대개 구체적으로 제시되는 경우가 많다.

2. 프리어나운싱 시점: 미국 기업들을 대상으로 한 설문조사 자료에 의하면 신제품 프리 어나운싱의 시점은 좋게는 신제품 출시 전 1 개월 전에서 길게는 몇 년 전에도 시행하는 것 으로 보고되고 있다 (Eliashberg and Robertson 1988). 평균은 신제품 출시 전 3 6 개월 전인데, 산업별로 신제품 프리어나운싱 시점이 상당히 상이한 것으로 나타나고 있다. 컴퓨터 산업에 
서는 빠른 프리어나운싱의 경우 출시 6 개월 전부터 시행되고 있으며, 자동차 산업의 경우는 빠론 프리어나운싱이 출시 2 년 전부터 시행되는 경우도 많다 (Lilly and Walter 1997). 신제품 개발, 출시과정에서 프리어나운성이 발생하는 시점도 제품영역별로 상이한데, 컴퓨터 메인 프레임 시장에서의 신제품 프리어나운싱 시점을 살펴보면 대개 alpha test (기업내부에서의 제 품 성능테스트) 후 어느 시점에서 발생하게 된다 (Rabino and Moore 1989).

<그림 1> 메인프레임 시장에서의 신제품 프리어나운싱 시점

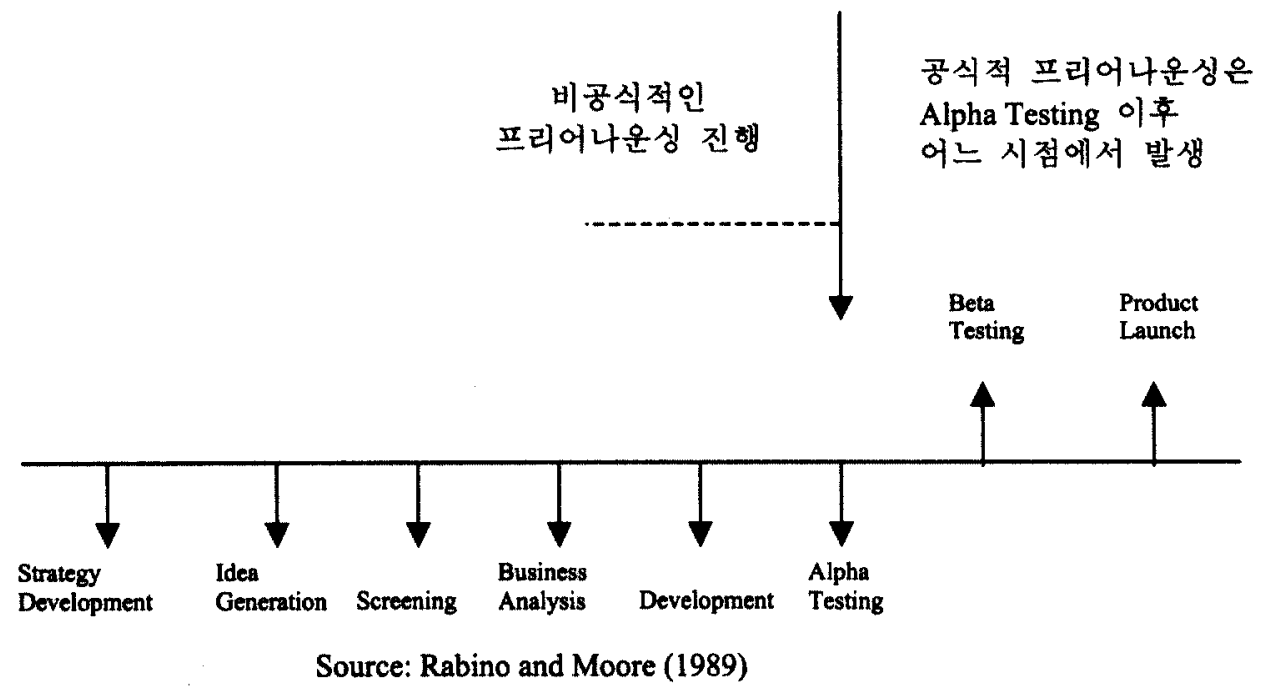

3. 사용매체: 어떤 매체률 사용하느냐 하는 의사결정이 신제품 프리어나운싱의 성공에 결 정적 역할을 할 수가 있는대, 그 이유는 매체가 신제품의 목표 소비자들과 최초의 접촉을 하기 때문이다 (Lilly and Walters 1997). 일반적으로 신제품 프리어나운싱의 매체로는 다양한 매체가 사용될 수 있다. 신제품 프리어나운싱은 보도자료 (press release), 매스컴발표희 (press conference), 비망톡 (memorandums), 광고 둥을 통해 이루어질 수 있으며, New Product Alert 나 Grocer 같은 상거래 발간물 (trade publication), 또는 Wall Street Journal, Advertising Age 같은 비 즈니스 경향의 매체를 퉁해 행해질 수도 있다. 신제품 프리어나운싱의 성공을 위해서 어떤 매체를 할용할 것인가의 결정은 신제품 프리어나운싱의 목표 집단이 누구인가에 달려있다. 예를 들면, 신제품 프리어나운싱의 대상이 일반 소비자들인 경우 대중 매체를 통한 광고를 사용하는 것이 바람직할 것이며, 소매 바이어들을 대상으로 한다면 박랍희 (trade show)가 적 절할 것이다.

\section{4. 신제품 프리어나운싱의 헤택 및 위혐}

서두에서 밚혔듯이 신제품 프리어나운싱은 기업이 특정의 전략적 목적을 염두에 두고 실 
행하는 행위이다. 신제품 프리어나운싱의 전략적 목적에 해당되는 것들은 크게 아래의 5 가 지로 나누어 뷸 수 있다.

- 소비자들의 제품구매 연기 및 해당제품 대기: 하이테크 제품의 경우 제품수명주기가 매우 짧기 때문에 신제품을 출시하기 전에 미리 수요를 확보해 놓지 않으면 채산성 을 충분히 확보하지 못할 수 있다. 따라서 하이테크 기업은 현재 제품구매를 고려하 고 있는 소비자들에게 프리어나운싱을 통해 제품구매를 신제품이 나울 때까지 연기 하도록 할 수 있는 것이다.

- 기술선도 이미지 형성 및 유리한 소비자 선호점 선점: 하이테크 기업들의 경우 소비 자들에게 해당 기업이 기술면에서 경쟁기업 들에 비해 앞서 나간다는 이미지를 형 성해 줄 필요가 있다. 따라서 하이테크 기업들은 신제품 프리어나운싱을 경쟁기업보 다 빨리 시행함으로써 기술선도 이미지를 구축할 수 있으며, 아울러 유리한 소비자 선호점율 선점할 수 있다.

- 구전효과 활용: 하이테크 기업은 신제품이 시판되기 전에 소비자들의 해당 신제품에 대한 관심을 고양시킬 필요가 있다 (Wind and Mahajan 1987). 하이테크 제품의 경우 소비자들이 해당제품의 기술적 특성이나 장점둥에 대해 제대로 판단하는데 어느 정 도 시간이 요구되므로 프리어나운싱을 퉁해 소비자들이 제품에 대해 판단할 시간을 주고 아올러 구전효과를 유발, 제품에 대한 줗은 이미지를 시판 전에 형성할 필요가 있다.

- 신제품에 대한 반웅 및 수요 예측: 신제품의 높은 실패율을 감안할 매 신제품 출시 전에 해당제품의 성공가눙성을 예측하는 것이 매우 중요하다. 신제품 프리어나운싱 의 경우 해당 제품에 대한 소비자들의 반웅을 미리 체크합으로써 신제품 출시 의사 결정에 유용한 정보률 제공할 수가 있다 (Brockhoff and Rao 1993).

- 유통망의 협조유도 용이: 유통업자들의 경우 신제품 중 성공가눙성이 입중되지 않은 제품들의 취급을 꺼리는 경우가 많다. 이 경우 기업은 신제품 프리어나운싱을 통해 해당 제품에 대한 여론을 형성합으로써 해당제품이 출시될 때 유통업자들의 적극적 인 협조를 얻어낼 수 있다.

- 경쟁자 진입 방지: 시장에서 우세한 지위를 확보하고 있는 기업의 경우 경쟁자들의 시장진입올 막기위해 신제품 프리어나운싱을 할용할 수 있다. 현재 잘 나가는 제품 의 판매가 정점에 이를 때쯤 미리 차세대 제품을 프리어나운싱 함으로써 유력한 잠 재적 경쟁기업이 실제 시장에 뛰어들 수 있는 기회를 제거 시켜 버리는 것이다.

신제품 프리어나운싱은 상기한 전략적 장점을 가지고 있는 반면, 잘못되었을 경우 위헙도 따르게 된다. 신제품 프리어나운싱에 수반되는 위혐으로 다옴의 4 가지를 들 수 있다.

- 바랍직하지 않은 경쟁자 반응 유발: 신제품 프리어나운싱은 바랍직하지 않은 경쟁자 의 대처행위를 유발시킬 수 있다. 예를 들면 경쟁기업 들이 신제품 프리어나운싱을 
보고 유사한 제품의 개발에 착수할 있으며, 경쟁사들이 기술적으로 유사한 제품을 개발할 수 없더라도 허위로 유사한 프리어나운싱을 합으로써 자사 신제품 프리어나 운싱의 전략적 효과를 반감시킬 수도 있다.

- 과장된 주장과 소비자 실망: 신제품 프리어나운싱을 하는 경우 보통 기업들이 해당 제품의 기술적 수준이나 출시 일에 관해 과장하는 경우가 많다. 만일에 해당 기업이 공표한 제품의 기술적 수준보다 못한 제품을 시판하거나 출시 일을 지키지 못할 경 우 해당기업의 명성에 타격을 줄 뿐 아니라 소비자들의 실망으로 이어질 수 있다. Jung and Steckel (2000)온 제품질의 과장은 소비자들의 기대수준을 높이게 되므로 해 당기업이 프리어나운싱한 수준의 제품 질을 제공하지 못하게 되면 격심한 판매부진 을 경헙할 수 있다는 것을 보여주고 있다.

- 부서간 갈둥 노출: 일반적으로 마케팅 부서는 신제품 프리어나운싱을 선호하는 반면 기업의 R\&D, 생산부서는 프리어나운싱한 제품사양을 꼭 맞추어야 하는 부담을 안게 되므로 싫어하는 경우가 많다. 따라서 신제품 프리어나운싱이 마케텅 부서와 R\&D, 생산 부서간의 갈둥울 심화시킬 가능성이 있다.

- 반 경쟁행위에 대한 소동 가능성: 신제품 프리어나운싱 자체가 존재하지 않는 제품 에 대해 소비자들에게 광고하는 것이기 때문에 시장의 자유 경쟁을 침해하는 행위 로 푠명되는 경우에는 법적 소송의 대상이 될 수도 있다. 톡히 과장된 선전을 수반 하는 프리어나운싱의 경우 시장지배자가 경쟁자의 시장진입을 방지하기 위해 악용 할 수가 있으므로 정부나 경쟁기업으로부터 자유경쟁에 위반되는 행위로 소송을 당 할 가능성도 있다.

\section{5. 신제품 프리어나운싱에 대한 소비자, 경쟁자 반웅}

\section{1. 경쟁자 반웅}

신제품 프리어나운싱에 대한 경쟁기업의 반웅은 반웅의 강도 측면에서 크게 아래의 4 가 지로 나누어 고찰해뵬 수 있다 (Robertson et al. 1995).

- 일체 반웅을 하지 않음

- 반웅을 하기 전에 소비자들의 반웅을 보며 기다립

- 반대적인 시그녈 (counter signal)을 보념

- 톡정 행위를 실행함

반대적인 시그널을 보내는 경우 자사가 개발 중인 신제품 (프리어나운싱한 제품과 유사하 거나 보다 우수한 제품)을 프리어나운싱할 수가 있으며, 또한 허위로 프리어나운싱된 제품 과 유사한 제품을 개발 중이라고 프리어나운싱할 수 있다. 특정 행위를 실행하는 경우는 크 게 제품에 관련된 행위와 다른 마케텅 믹스 행위로 구분할 수 있다. 경쟁기업은 신제품 프 리어나운싱에 대한 반웅으로 실제 자사가 개발중인 유사품의 출시를 앞당길 수 있으며, 자 
사의 기존 경쨍제품의 가격을 심하게 인하함으로써 프리어나운싱한 제품에 대한 소비자들의 반응을 격감시킬 수도 있다.

\section{2. 소비자 반응}

신제품 프리어나운싱에 대한 소비자들의 반웅은 크게 아래의 두 가지로 나누어 볼 수 있 다.

- 제품 구매 연기 및 프리어나운싱 제품 대기: 신제품이 프리어나운싱 되면 현 재 해당 제품류를 구입할 것올 고려하고 있는 소비자들, 특히 혁신 소비자들 (innovators)이 제품 구매를 연기하고 해당 제품이 시장에 나오기까지 기다리 게 된다.

- 구전행위: 프리어나운싱된 신제품에 관심을 가지고 있는 소비자들의 경우 이 를 주위사람 들에게 소개함으로써 구전효과가 발생하게 된다.

\section{6. 프리어나운싱 의사결정의 개념적 모형도}

4 장에서 기술했듯이 신제품 프리어나운싱의 경우 다수의 혜택과 위험이 수반되므로 프리 어나운싱 여부를 결정할 때는 이들 혜택과 위헙들 중 어떤 요소들이 자사에 어느 정도 더 심각하게 영향을 미치는가를 면밀히 검토해 볼 필요가 있다. 그리고 5 장에서 기술했듯이 신 제품 프리어나운싱에 대한 소비자/경쟁자들의 반웅도 다양하므로 신제품 프리어나운싱을 하 기 전에 어떤 반웅이 가장 가능성이 있을 것인가에 대해서도 고려해 볼 필요가 있다. 지금 까지 제시된 기업의 신제품 프리어나운싱 의사결정과 관련된 이슈들을 개념적 모형도 (conceptual framework) 를 이용, 퉁합해보면 <그림 2 >와 같다. <그립 2> 에서 제시된 바와 같 이 기업의 관리자는 먼저 신제품 프리어나운싱의 효용과 위헙을 평가하고 이를 기반으로 신 제품 프리어나운싱 여부를 결정한다. 일단 신제품 프리어나운싱을 하기로 결정하고 나면, 프 리어나운싱과 관련된 3 가지 세부 의사결정울 행하게 된다. 세부 의사결정 내용을 기반으로 신제품 프리어나운싱이 집행되면, 소비자, 경쟁자의 반웅이 뒤따르게 된다. 


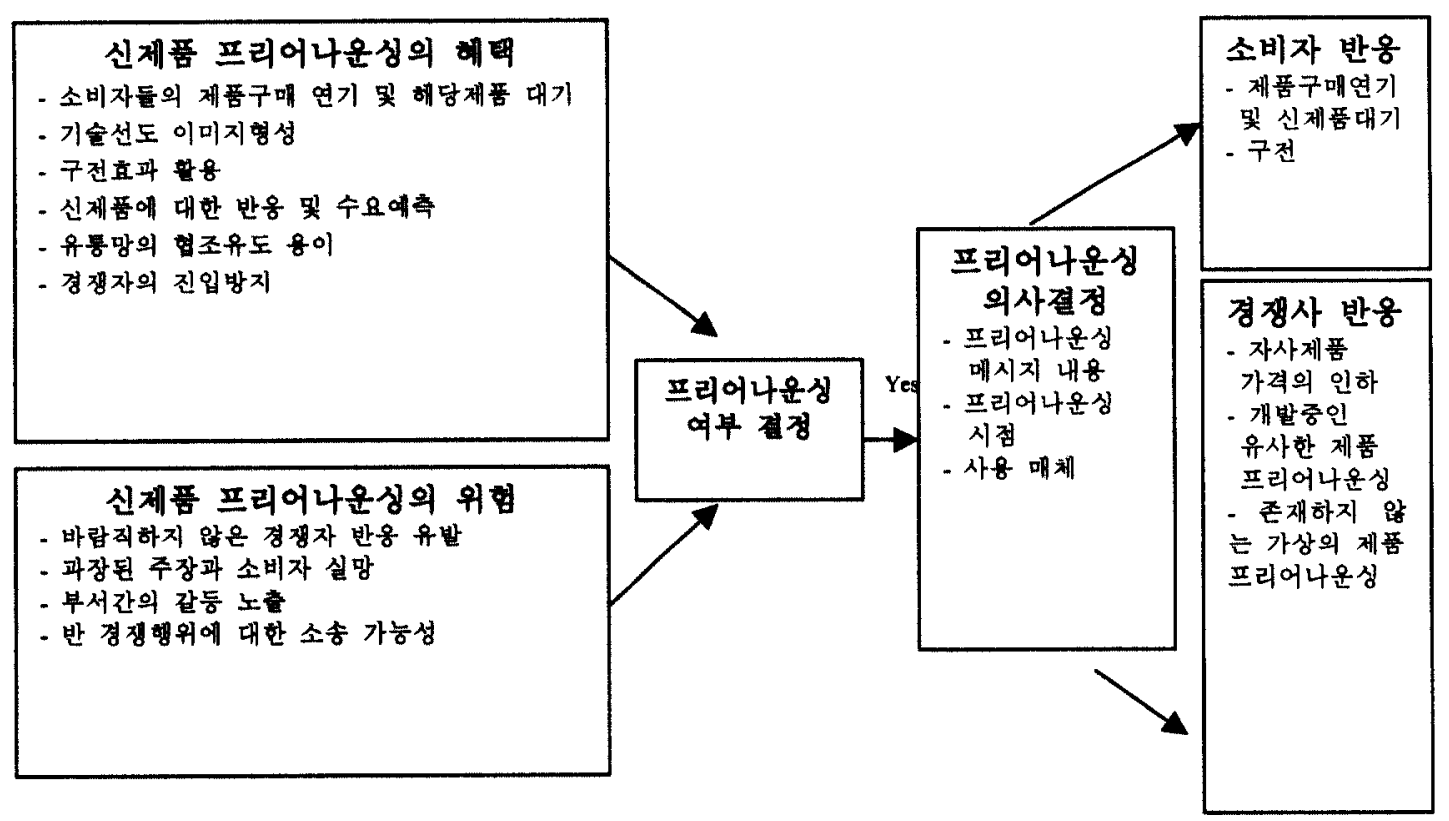

\section{7. 신제품 프리어나운싱에 관한 기존 연구}

신제품 프리어나운싱에 판한 기존 연구들은 크게 연구 방법적인 측면에서 두 가지 흐름으 로 분류할 수 있다

\section{1. 경험적 연구 (empirical studies)}

신제품 프리어나운싱과 관련하여 최초로 행해진 연구는 Eliashberg and Robertson (1988) 이 다. Eliashberg and Robertson (1988)은 먼저 기업의 프리어나운싱 결정에 영향을 미치는 요인들 로 크게 시장경쟁 관련 요소들과 소비자 관련 요소들을 들 수 있다고 주장했다. 프리어나운 싱을 하는 기업의 경우 프리어나운싱과 관련된 위험보다 혜택에 중점을 두는 반면, 하지 않 는 기업은 위헙에 보다 중점을 둔다고 주장하며 기업의 신제품 프리어나운싱 여부에 영향을 주는 요인들을 경헙적으로 검중하였다. 이에 따르면 시장에서의 지위 (dominance in category), 기업의 규모, 시장의 경쟁정도, 소비자 학습 요구정도, 소비자 스위칭 코스트 둥이 프리어나 운싱 여부에 영향을 미치는 것으로 나타났다.

Rabino and Moore (1989)는 하이테크 기업 관리자들과 인터뷰를 퉁해 몇 가지 중요한 사실 을 발견하였다. 이에 따르면 신제품 프리어나운싱은 분리된 의사소퉁 전략이라기보다는 기 업의 신제품 출시 전랴의 정점을 이루는 것이라는 점과, 목표 고객에 효과적으로 어필하기 위해서는 목표고객의 성향에 적합한 프리어나운싱 내용, 미디어, 시점이 결정되어야 한다고 
밝히고 있다.

Robertson et al. (1995)은 신제품 프리어나운싱에 대한 경쟁기업의 반웅에 초점을 두고 보다 적대적인 경쟁자의 반응올 유발시키는 요인들을 경험적으로 검중하였다. 이에 따르면 프리 어나운싱 메시지가 적대적일수록, 프리어나운싱 메시지의 신뢰도가 높을수록, 경쟁기업이 해 당 제품 카테고리에 보다 깊이 관련되어 있을수록, 경쟁기업의 반웅 강도가 강하며, 반웅도 가격 등 다른 마케팅 믹스가 아닌 제품영역에 초점이 맞추어진다고 밝히고 있다.

Lilly and Walters (1997)는 신제품 프리어나운싱 시점에 연구의 초점을 두고 프리어나운싱 시점에 영향을 줄 수 있는 요인들을 제시하고 있다. 이에 따르면 경쟁기업의 예상 반응, 제 품의 복잡성, 혁신성 등 제품관련 특성, 구매과정의 시간적 길이 등 소비자 관련 요인, 기업 관련 특성들이 신제품 프리어나운싱의 시점을 결정한다고 밝히고 있다. 그리고 이들 특성들 의 상대적인 중요도는 신제품 프리어나운싱의 목적과 목표대상이 누구냐에 달려 있다고 밝 히고 있다.

정 헌수 (2000)는 프리어나운싱이 성공하기 위해서는 프리어나운싱의 일반적인 목표 대상 인 혁신소비자 (innovators)들의 인적 특성에 맞게 메시지형태를 설계해야 한다는 인식 하에 혁신소비자 들의 톡성에 적합한 메시지 형태를 개발, 경험적으로 검중 하였다.

\section{2. 이론적 모델 개발 (theoretical model development)}

신제품 프리어나운싱이라는 현상을 모델을 퉁해 살펴보려는 최초의 노력은 Farrell and Saloner (1986) 에서 찾아 볼 수 있다. Farrell and Saloner (1986)는 신제품의 기술적 형태 (compatibility)와 소비자의 신제품 채택간의 관계를 게임모델을 퉁해 살펴보면서, 신제품을 출시하는 기업이 프리어나운싱 전략을 구사하게 되면 고객베이스 (installed base)를 확대시킬 수 있기 때문에 소비자들의 해당 신제품 채택을 촉진시킬 수 있다는 것을 보여주었다. 물론 이 연구는 신제품 프리어나운싱이라는 주제에 초점을 맞추고 게임을 개발한 것은 아니지만 연구의 부산물로 신제품 프리어나운싱이 소비자의 신제품 채택을 촉진 시킬 수 있음을 모델 을 통해 보여준 최초의 연구이다.

Bayus, Jain and Rao (1997)은 기업의 신제품 프리어나운싱 시점에 관한 의사결정을 게임 모 델을 통해 살펴보았다. 이에 따르면 프리어나운싱 시점은 기업이 신제품과 관련하여 기업이 누리는 제조원가의 효율성을 시그널링하는 도구라며, 게임 모델울 통해 생산 효율이 높은 거대 기업들은 빠른 시점을 프리어나운싱하고 출시기일올 지키는 반면, 생산효율이 낮은 기 업들은 빠른 시점을 프리어나운싱 하더라도 이를 지키지 못한다는 것을 보여주었다.

Jung and Steckel (2000)온 신제품 프리어나운싱 실행 시 일반적으로 행해지는 제품의 질적 수준 과장에 연구의 초점을 맞추고 기업의 제품 질 과장 (vaporware) 의사결정을 게임 모델 을 통해 살펴보고 있다. 이에 따르면 프리어나운싱하는 기업이 신제품의 질을 과장할 것인 가 여부는 과장으로 인한 혜택 (consumer delaying effect: 소비자들이 구매를 연기하고 해당 제품을 대기) 과 위험 (consumer disconfirmation effect: 소비자들의 실망으로 인한 판매저하) 중 어느 요인이 더 강하게 작용하느냐에 달려있다고 밝히고 있다. 일반적으로 기업이 제품 의 질을 과장하게 되면 소비자돌의 기대수준이 중가하게 되는데, 소비자 확인효과 (consumer disconfirmation effect)가 큰 상황에서는 큰 판매 부진이 예상되므로 상대적으로 신제품의 질 을 과장 프리어나운싱할 유인이 적어진다는 것올 보여주고 있다. 


\section{8. 한국기업의 신제품 프리어나운싱 전략 활용}

한국 기업들의 신제품 프리어나운싱 활용 현황에 관해서는 공식적인 조사가 행해겨 있지 않은 관계로 구체적인 할용정도에 관한 자료률 제공할 수 없다. 그러나 저자가 한국의 주요 하이테크 기업 관련자들과 인터뷰한 결과, 이들이 신제품 프리어나운싱 전략을 자주 사용하 고는 있지만, 신제품 프리어나운싱의 다양한 효용과 위헙에 관해 충분히 인식하지 못하고 있는 것으로 나타넜다.

경쟁 기업보다 앞서 신제품을 공표하는 것이 자사에 도움이 될 것이라는 개념은 가지고 있으나, 구체적으로 어떤 형태로 도움이 될 것이며, 또한 어떤 형태의 위혐이 수반될 수 있 는가에 관해 엄밀히 평가하지 못한 상태에서 신제품 프리어나운싱 전략을 사용하고 있는 것 이다. 따라서 향후 한국의 하이테크 기업들에게 신제품 프리어나운싱의 구체적 효용과 위헙 을 인식시키려는 노력이 있어야 할 것으로 본다.

신제품 프리어나운싱의 3 가지 구체적 의사졀정 내용 가운데 한국 기업들이 특히 주목해 야 할 것으로 판단되는 것은 프리어나운싱 시점이다. 미국이나 일본에 비해 한국에서의 신 제품 전파속도가 월둥히 빠르다는 것은 이미 잘 알려져 있다. 따라서 한국의 경우 신제품 프리어나운싱의 적정 시점이 미국에서 각 산업별로 보고된 시점보다 다소 빨라야 할 것으로 판단된다.

\section{9. 결론 및 향후 연구방향}

Arthur (1996) 에 따르면 다가오는 지식기반 경제 하에서 기업이 성공적인 비즈니스를 수 행하기 위해서는 경쟁자보다 우수한 제품을 시장에 먼저 출시하는 것 이상의 적극적 전략이 요구된다고 밝히고 있다. 신제품 프리어나운싱온 그러한 전략들 중의 하나로 신제품의 성공 가능성을 높이기 위해 기업이 사용할 수 있는 중요한 소비자와의 심리적 플레이라고 할 수 있다. 무엇보다도 첨단 기술의 발전과 산업에서의 신기술 채택속도의 가속화로 제품라이프 사이클이 위협적일 정도로 짧아지고 있는 현 상황에서 신제품 프리어나운싱 전략의 활용은 기업들에게 선택의 문제가 아니라 신제품의 성공올 위한 필수적인 전략으로 까지 받아들여 지고 있다.

하이테크 기업은 신제품 프리어나운싱 전략을 퉁해 해당 신제품에 대한 소비자들의 관심 을 이꿀어 낼 수 있을 뿐만 아니라, 소비자 반웅을 퉁해 해당 제품의 성공가능성을 타진해 볼 수 있으며, 무엇보다도 현재 구매를 고려중인 소비자들의 제품구매를 연기시킴으로써 신 제품에 대한 수요를 중대 시킬 수 있다. 반면, 신제품 프리어나운싱은 경쟁자의 바람직하지 않은 반웅을 유발시킬 수 있으며, 프리어나운싱한 제품 사양을 출시하지 못했을 경우 기업 의 명성 및 매출에 타격을 입을 수도 있다. 따라서 기업이 신제품 프리어나운싱 관련된 다 양한 의사결정을 행할 때는 이와 같은 요인들을 면밀히 검토해보고 결정해야 할 것이다.

현재 한국에서 신제품 프리어나운싱에 관한 연구가 전혀 행해지고 있지 않다는 점에서 앞 으로 이 분야에 대한 특별한 관심이 요구된다 하겠다. 한국 기업들, 톡히 하이테크 기업들의 신제품 프리어나운싱 전략 활용 현황에 관한 연구가 무엇보다도 먼저 행해져야 할 것이며, 
정 헌수 $(2000)$ 와 같은 소비자 관점에서의 연구도 많이 행해져야 할 것으로 본다. 아울러, 경험적 연구에 비해 이론적 모델방법올 사용한 연구가 적다는 점에서 신제품 프리어나운싱 과 관련된 다양한 의사결정 내용 및 상황올 모델화하는 노력이 있어야 할 것으로 본다. 


\section{<참고문헌>}

정 헌수 (2001), “신제품 프리어나운싱 전략에서의 메시지 효과 제고방안: 메시지 특성과 혁 신소비자 특성의 적합성 확립을 중심으로," 소비자학 연구, 제 12 권, 제 2 호, 37-54

Arthur, W. Brian (1996), "Increasing Returns and the New World of Business," Harvard Business Review, July-August, 100-109

Bayus, Barry, Sanjay Jain, and Ambar Rao (1997),"Is It Real or Is It Vaporware? An Analysis of Preannouncements in the Software Industry," Working Paper, The University of North Carolina at Chapel Hill

Brockhoff, K. Klaus and Vithala R. Rao (1993), "Toward a Demand Forcasting Model for Preannounced New Technological Products," Journal of Engineering \&Technology Management, Vol. 10 (Sept), 211-2 Computerworld (1994), "Announce," July 9, p 14

Eliashberg, Jehoshua and Thomas Robertson (1988), "New Product Preannouncing Behavior: A Market Signaling Study," Journal of Marketing Research, 28(Aug), 282-92

Farrell, Joseph and Garth Saloner (1986), "Installed Base and Compatibility: Innovation, Product Preannouncement, and Predation," The American Economic Review, 76 (No. 5), 940-55

Jung, Heonsoo and Joel Steckel (2000), "Signaling Quality with New Product Preannouncements: Vaporware and the Role of Reference Quality," Doctoral Dissertation, New York University

Lilly, B. and Rockney Walter (1997), "Toward a Model of New Product Preannouncement Timing," Journal of Product Innovation Management, 14(Feb), 1-20

Rabino, Samuel and Thomas E. Moore (1989), "Managing New-Product Announcements in the Computer Industry," Industrial Marketing Management, 18, 35-43

Robertson, Thomas, Jehosua, and Talia Rymon (1995), "New Product Announcement Signals and Incumbent Reactions," Journal of Marketing 5 (July), 1-15

Standard \& Poor's (1998), Industry Survey: Computers Hardware, February 26, p. 15

Wind, Jerry and Vijay Mahajan (1987),"Marketing Hype: A New Perspective for New Product Research," Journal of Product Innovation Management, 4, 43-49. 